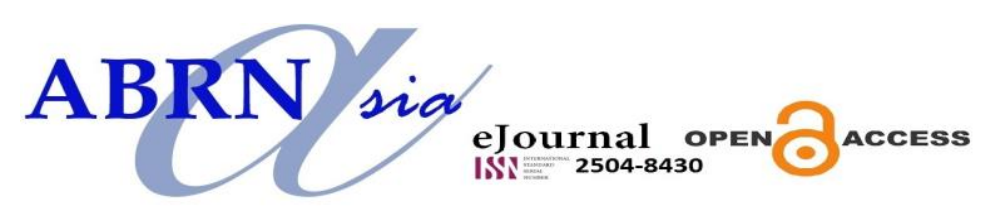

\title{
A CONCEPTUAL STUDY ON THE IMPACT OF PARENTAL INFLUENCE IN IMPROVING FINANCIAL LITERACY OF UNIVERSITY STUDENTS
}

\author{
Gianina Nadya Putri ${ }^{1}$, Raden Aswin Rahadi ${ }^{2}$, Adhya Rare Tiara ${ }^{3}$ \\ ${ }^{1,2,3}$ School of Business and Management, Institut Teknologi Bandung, 40132 Bandung, \\ Indonesia
}

\begin{abstract}
Financial independence usually begins when someone starts attending university because at that time parents usually give authority to their children to manage their own finances. Financial literacy is one of the competences which people really need in current times to make various financial decisions. Parents become very critical agents in the development of children's financial literacy level and it is proven that there is a relationship between financial literacy and parental financial socialization. According to this study the factors that influence the success of parental socialization in increasing children's financial literacy are parents' experience, role modeling, financial communication, money allowance, and financial monitoring.
\end{abstract}

Keywords: financial literacy, financial socialization, conceptual study, parents, university students

\subsection{INTRODUCTION}

Industry 4.0 marked the advances in technology which required a tech-savvy society. Every aspect in our life impacted so much by that, such as the financial sector. Financial sectors including bank, insurance company, multi-finance, and so forth. To fulfil the high demand of society's financial needs in everyday life, the financial sectors offer many interesting financial products.

In the past five years, Indonesian have been hit by the trend of mobile payment to promote Cashless Society. Some names like Gopay, OVO, Dana, and Link Aja are digital payments which are very famous among locals and now their service is already widespread all over Indonesia. Reported by Indonesia CNBC (2020) in Ipsos Marketing Summit 2020: Indonesia The Next Cashless Society to 1000 respondents spread all over Indonesia, shown that around $25 \%$ of Indonesian use digital payment, they perceived it as a pleasant experience and as much as $26 \%$ respondents feel safer, more comfortable and confident in using digital payment.

By the features provided by the platform, people who want to get loans also get so much easier in the procedure compared to the past time. However by this easiness and the variety of financial products offered, people might make wrong decisions instead they get lost financially. To prevent people with this kind of situation, people need to be equipped with some competences in finance which could be mirrored by how their financial literacy level is in facing this Cashless Society era. 


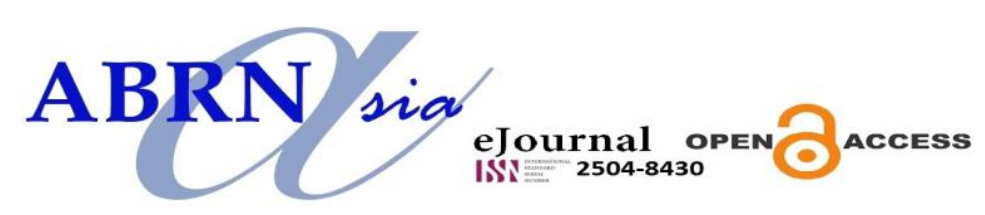

Asia Pacific Journal of Social Science Research

Volume 5 Issue 12020

Financial literacy is the skill to examine new and complex financial instruments and to make rational judgments for both the choice and extent of use of instruments that would be in their best long-term interest. (Mandell, 2007). Financial literacy is a crucial part of financial decision making (Lusardi et al., 2010) and successful adult life (Jian \& Joyce, 2010) because people already confront complicated financial decisions since young age and financial mistakes can be costly (Lusardi et al., 2010)., that's how important financial literacy is.

In this research, the author specifically wants to study about university students. University students are an interesting subject to study because university students are in the age where they are given the authority to manage their own money for the first time. Some of them might be living away from their parents and living alone to pursue their studies. This period is often considered as the transitional stage of financial independence. But in reality, university students often experience numerous difficulties related with adjusting to living away from home especially the first-year university students (Tinto, 1998).

Most university students are not yet financially independent but are actively learning the skills needed to be financially independent. Furthermore, the key to achieving adult status is financial independence (Arnett, 2004). Bad personal money management is often found by university students because most of them are given the trust by their parents to manage their own finances for the first time in this stage. Thus it's crucial for the university student which is categorized in the age group of young adults to start learning about finance during adolescence in order to have successful transition to adulthood where their attitude starts from supportive social networks such as parents (Jian \& Joyce, 2010).

The channel who are responsible for financial knowledge and awareness among young adults on financial planning and its impact on money management are parents, educational institutions, and the government (Sundarasen et al., 2016). Specifically, parents are the primary socialization agent. Parents teach children how to act by relying on their values, beliefs, and knowledge (Bandura, 1986; Clarke et al., 2005), thus shaping their children's attitude toward finances as well as their behavior (Jorgensen \& Savla, 2010).

\subsection{LITERATURE REVIEW}

\subsection{Financial Literacy}

According to OECD (2013) financial literacy is a combination of skill, behaviour, awareness, attitude and knowledge of a person that is required to build a sound financial decision leading towards the accomplishment of becoming financial well-being. Individuals are acknowledged financially literate when they are proficient and practice financial inclusion along with knowledge they have learned. As people become more literate they develop into more financially sophisticated and it is expected that this may also imply that an individual can be more proficient (Moore, 2003). The Financial knowledge has relation with financial behaviour, attitude, and influence (Jorgensen, 2007). The worst fields of financial behavior appear to be related to budgeting, planning ahead, product selection and the use of professional advice (OECD, 2018)

This research focuses to find out how the influence of parent socialization with the financial literacy level of their children who are currently studying at a university located in Bandung, Indonesia. This research also wants to find out what factors are significant in this process and aimed to give the best recommendation. 


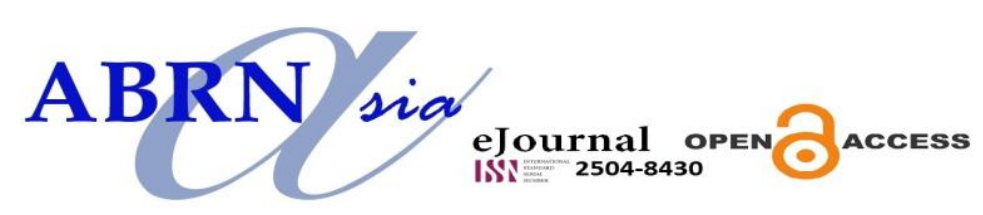

Asia Pacific Journal of Social Science Research

Volume 5 Issue 12020

\subsection{Financial Socialization}

Financial socialization is the process of teaching values, attitudes, standards, norms, knowledge, and behaviors that contribute to the financial survival and the success of individuals (Danes, 1994). The financial socialization perspective presuppose that "socialization takes place through interaction of the person and various agents in specific social settings" (McLeod \& O'Keefe, 1972). Previous research has shown that people access financial knowledge not only from financial educational networks but also from interactions with socialization agents such as family, friends, media and schools (Curto, 2010).

\subsection{University Students}

Students in broad have a low level of financial literacy (Xiao et al., 2014). Financial literacy of students affected by demographic variables such as social background, financial attitude, financial knowledge and family sophistication (Ibrahim et al., 2009). Even though students living surrounded by financial activities, students are taught very little about how to practice the financial matters properly (Conci, 2008). A variety of teaching approaches might be used to increase students' knowledge (Xiao et al., 2014).

\subsection{Parents as the Agent of Socialization}

Parents have been found to shape the socialization of their children (Jorgensen \& Savla, 2010). Even as they get in early adulthood, parental influence remains a potentially critical socialization agent (Tang and Peter, 2015). Soroukou and Weissbrod (2005) said, first-year university students (both males and females) consider their parents to be supportive, especially during more severe periods. Since most young people are dependent upon parents for financial support during the transitional period (Schoeni and Ross 2005). Parents can be both direct teachers and useful role models in the financial development of their children (Jian \& Joyce, 2010).

\subsection{Previous Studies}

Researchers make summaries of article journals using tables with topics that correspond to the research topic of the researcher. Topics related to financial literacy, parents, and students. This literature will assist researchers in creating the conceptual frameworks from the previous studies.

Table 1 Previous Studies

\begin{tabular}{llll}
\hline Author (Year) & \multicolumn{1}{c}{ Description } & \multicolumn{1}{c}{ Key Point } & Methodology \\
\hline $\begin{array}{l}\text { Tang and Peter } \\
\text { (2015) }\end{array}$ & $\begin{array}{l}\text { Determine the current roles of } \\
\text { financial education, financial } \\
\text { experience, and parent's } \\
\text { financial experience as } \\
\text { determinants of financial } \\
\text { knowledge acquisition. }\end{array}$ & $\begin{array}{l}\text { The roles of financial } \\
\text { education, financial } \\
\text { experience, and parents, } \\
\text { financial experience has } \\
\text { significant impact on } \\
\text { financial knowledge. }\end{array}$ & $\begin{array}{l}\text { ANOVA and Poisson } \\
\text { Regression, (main } \\
\text { effect and interaction } \\
\text { effect). }\end{array}$ \\
\end{tabular}




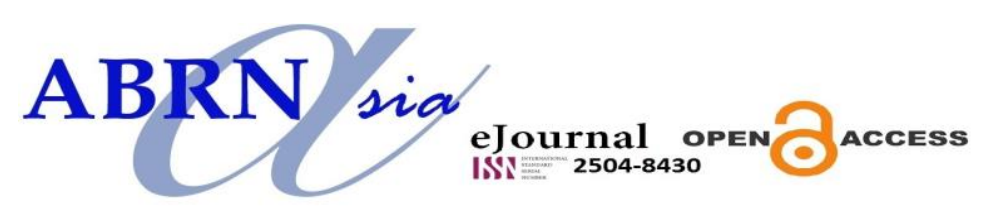

Asia Pacific Journal of Social Science Research

Volume 5 Issue 12020

Jorgensen et al. (2016)

Hanson \& Olson (2018)

Nidar \& Bestari (2012)

Serido J. \& Deenanath V. (2016)

Kim, J. \& Chatterjee, S.(2013)
Analyze the financial behavior of emerging adults and their relationship with their parents in achieving financial independence from family financial socialization.

Determine the correlation between financial literacy of college students and family communication patterns

Identify the factors affecting financial literacy of University students.

Analyze the ways that financial parenting pro- motes the acquisition of financial knowledge and skill and to propose how financial parenting promotes or constrains financial self-reliance

Which the family processes, such as parental warmth, parental financial monitoring and parental financial communication, and individual and parent factors affect their financial behaviors and financial attitudes.
Learned through parents' example was associated with higher levels of financial knowledge.

Young adults who grow up in a family with a strong conversation orientation possess greater financial knowledge.

The factors which influenced the personal financial literacy are knowledge of parents, pocket money / income, education level, faculty, parents income, and property insurance.

Parental role-modeling and explicit teaching are powerful socializing processes.

Respondents who had their spending monitored Logistic Model by their parents were significantly more likely to report being good at managing their own money.
Structural Equation Modeling (SEM).

Two-way ANOVA, correlation analysis, and multiple linear regression.

Logistic model regression.

Literature review.

\subsection{METHODOLOGY}

The first stage in conducting this research is to identify and define the main problem. After that, it break-down into research questions and objectives that this research wants to answer and solve. Next, do a literature review with article sources, journals, published books, and so forth. Then collecting primary data by distributing questionnaires with guidance from previous literature.

The questionnaires will be divided into three sections. The first section is demographic questions (full name, email, university, class year, type of living, source of money allowance, and source of financial knowledge). The second section is to measure 


\section{ABRT in if}

Asia Pacific Journal of Social Science Research

Volume 5 Issue 12020

financial literacy by assess financial knowledge, financial behaviour,and financial attitude. There will be 6 questions of financial knowledge (using multiple choice), 3 statements Financial behaviour (using 6-scale likert scale), and 3 statements of financial attitude (using 6-scale likert scale). The second section aimed to know the 'socialization method conducted by parents with (using 6-scale likert scale).

After all data has been collected, it will be checked with a statistical tool and transformed into information. The last stage of this research is providing conclusion and recommendation which will be used for financial literacy program conductors or used for further research.

\subsection{RESULTS AND DISCUSSIONS}

Financial literacy of university students is much influenced by parental financial socialization, based on literature that has been collected and reviewed. The role of parents is considered as critical, they are the first socialization agent to give and introduce financial issues since early adulthood. Parents can be both direct teachers and useful role models in the financial development of their children (Jian \& Joyce, 2010). Following below is a conceptual framework based on the researcher's understanding.

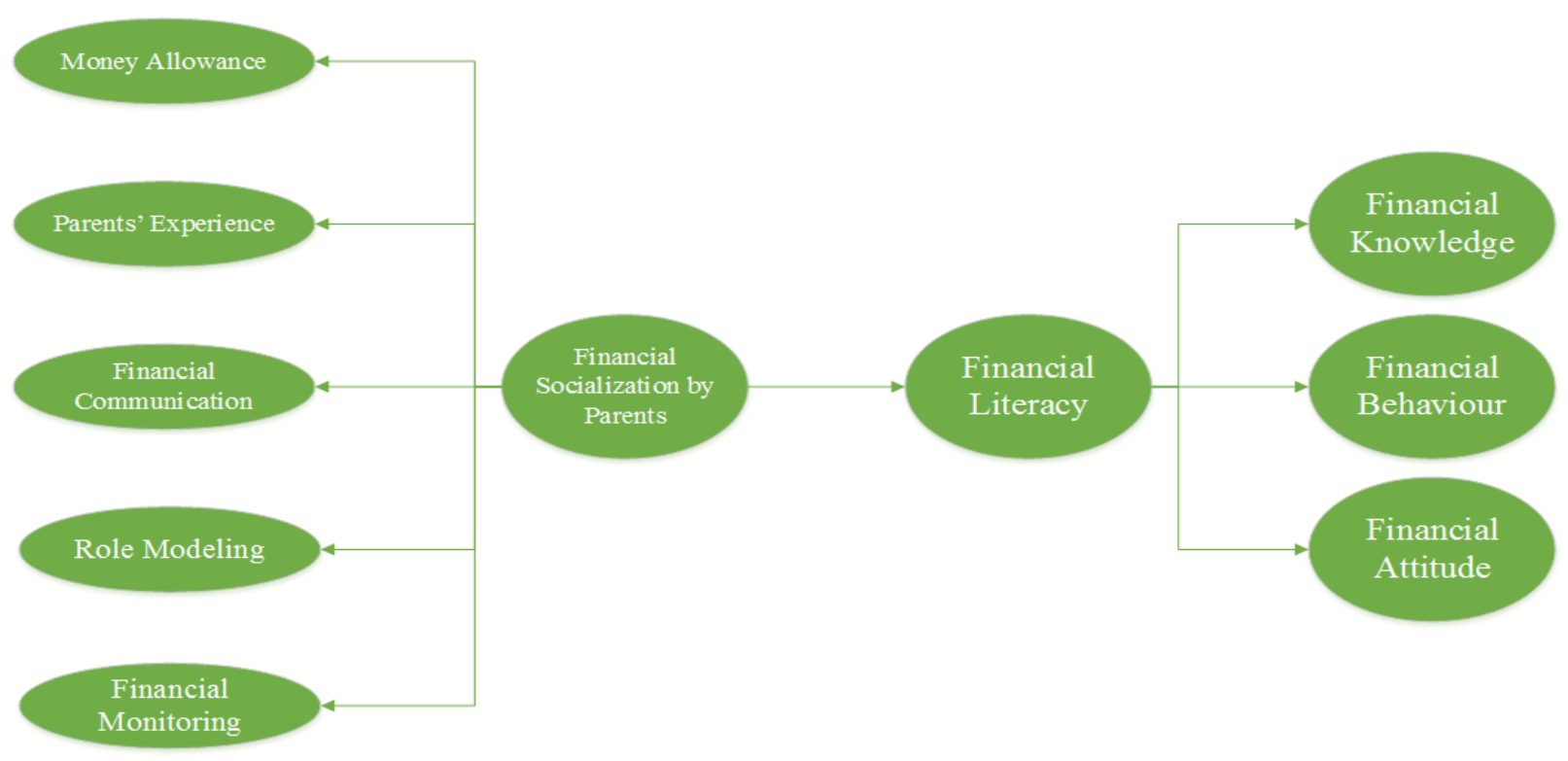

Fig.1 : Conceptual Framework for This Study from Author's Interpretation

Financial literacy level predicted by financial knowledge, financial behaviour, and financial attitude. Then the factors that influence the success of parents' financial socialization to their children can be due to parents' parents' experience (whether parents are familiar and use financial products then share experiences with their children), financial communication (do parents communicate directly in directing their children about finances), money allowance (how much the amount of allowance parents give to their children and the method to distribute it), and financial monitoring (whether parents always monitor the child's income or expenditure). The level of financial literacy of a university student can be explored by how their parents socialize financial problems. 


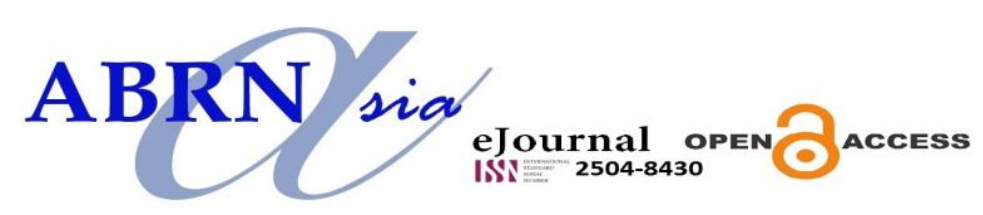

Asia Pacific Journal of Social Science Research

Volume 5 Issue 12020

\subsection{CONCLUSION}

Based on the data that has been collected, financial literacy has a relationship with how parents view financial socialization and there are a variety of methods and ways for it. It can be direct or indirect. Direct for things that are directly communicated such as financial communication and indirect ones such as parents' experience and money allowance.

Next researcher will check this result by using both qualitative and quantitative approaches. Researchers will also find the relationships between each variable using linear regression. The outcome of this study can be used by many stakeholders such as for parents, children, government, researchers, organizers of financial socialization, and so forth.

\subsection{FUTURE RESEARCH}

By making this conceptual study, researchers will use this study to test and measure the financial literacy level of university students and its relationship with parental socialization located in Bandung, Indonesia. This study also could be used by other institutions such as government, event planner, and even parents as the part of evaluating the effectiveness of socialization in enhancing financial literacy level.

\section{REFERENCES}

[1] Arnett, J. J. (2004), "Emerging adulthood: The winding road from late teens through the twenties." Oxford: Oxford University Press.

[2] Bandura, A, (1986). "Social foundations of thought and action: A social cognitive theory." Englewood Cliffs, NJ: Prentice-Hall.

[3] Clarke, M. C., Heaton, M. B., Israelsen, C. L., and Eggett, D. L. (2005),“The acquisition of family financial roles and responsibilities",Family and Consumer Sciences Research Journal, Vol. 33 No. 4, pp. 321-340.

[4] CNBC (2020). Alasan Gopay, Dana, LinkAja, CS Kian digandrungi di RI. Retrieved from https://www.cnbcindonesia.com/tech/20200115122416-37-130148/alasan-gopay-danalinkaja-cs-kian-digandrungi-di-ri

[5] Conci, P. (2008), "Young adults found to lack personal finance skills," Columbia News Service, May 13: http://jscms.jrn.columbia.edu/cns/2008-05-13/conci-teenagersmoney [accessed November 5, 2008]

[6] Curto, V. (2010), "Financial Literacy among the Young: Evidence and Implications for Consumer Policy. PhD", Department of Economics, Dartmouth College.

[7] Danes, S. M. (1994), "Parental perceptions of children's financial socialization", Financial Counseling and Planning, 5, 127 - 146.

[8] Hanson, T. A. and Olson, P. M. (2018), "Financial literacy and family communication patterns", Journal of Behavioral and Experimental Finance. Elsevier B.V. doi:

10.1016/j.jbef.2018.05.001.

[9] Ibrahim, D. Harun, R., and Z. Isa. (2009).“A Study on Financial Literacy of Malaysian Degree Students."Cross Cultural Communication5(4): 51-59.

[10] Jian, J., \& Joyce, X. Æ. (2010), "Financial Socialization of First-year College Students : The Roles of Parents , Work , and Education". 1457-1470. https://doi.org/10.1007/s10964009-9432-

[11] Jorgensen, B. L. (2007), "Financial Literacy of College Students: Parental and Peer 


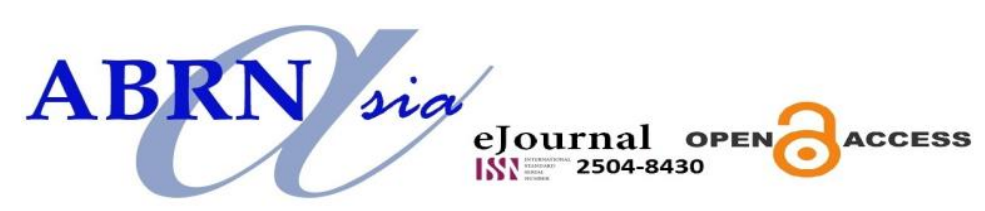

Asia Pacific Journal of Social Science Research

Volume 5 Issue 12020

Influences", .Master Thesis Submitted to Virginia Polytechnic Institute and State University in Master of Science in Human Development.Blacksburg, Virginia.

[12] Jorgensen, B. L., \& Savla, J. (2010)., "Financial Literacy of Young Adults : The Importance of Parental Socialization", 59(October), 465-478. https://doi.org/10.1111/j.17413729.2010.00616.x

[13] Jorgensen, B. L., Rappleyea, D. L., Schweichler, J. T., Fang, X., \& Moran, M. E. (2016), "The Financial Behavior of Emerging Adults : A Family Financial Socialization Approach", Journal of Family and Economic Issues. https://doi.org/10.1007/s10834-015-9481-0

[14] Krishna, A., Sari, M., \& Rofaida, R. (2007), Analisis Tingkat Literasi Keuangan Di

Kalangan Mahasiswa dan Faktor-Faktor yang Mempengaruhinya ( Survey Pada Mahasiswa Universitas Pendidikan Indonesia )", 1-6.

[15] Lusardi, A., Mitchell, O. S., \& Curto, V. (2010),"Financial Literacy among the Young."

The Journal of Consumer Affairs, Vol. 44(No. 2), 22. Retrieved from

http://www.councilforeconed.org/wp/wp-content/uploads/2011/11/Financial-Literacy-for-

Young-Lusardi.pdf

[16] Mandell, L. (2007), "Financial literacy of high school students", In J.J. Xiao (Ed.), Handbook of Consumer Finance Research (pp. 163-183). New York, NY: Springer.

[17] McLeod, J. M., \& O’Keefe, G. J., Jr. (1972), "The socialization prospective and communication behavior", In G. Kline, \& P. Tichenor (Eds.), Current perspectives in mass communication research (pp. 121-168). Beverly Hills, CA: Sage.

[18] Moore, D. (2003), "Survey of Financial Literacy in Washington State: Knowledge, Behavior, Attitudes, and Experiences", Technical Report n. 03-39, Social and Economic Sciences Research Center, Washington State University.

[19] Nidar, S. R. and Bestari, S. (2012), "Personal Financial Literacy Among University Students (Case Study at Padjadjaran University Students , Bandung, Indonesia)", World Journal of Social Sciences, 2(4), pp. 162-171.

[20] OECD. (2013), "Financial literacy and inclusion: Results of OECD/INFE survey across countries and by gender", Paris: OECD Centre.

[21] OECD. (2018). OECD / INFE TOOLKIT FOR MEASURING FINANCIAL LITERACY AND FINANCIAL INCLUSION. (May).

[22] Schoeni, R. F., \& Ross, K. E. (2005), "Material assistance from families during the transition to adulthood", In R. A. Settersten Jr., F. F. Furstenberg Jr., \& R. G. Rumbaut (Eds.), On the frontier of adulthood: Theory, research, and public policy (pp. 396-416), Chicago: University of Chicago Press.

[23] Serido, J. and Deenanath, V. (2016), "Financial Parenting: Promoting Financial SelfReliance of Young Consumers'", Handbook of Consumer Finance Research, (April), pp. 357-366. doi: 10.1007/978-3-319-28887-1.

[24] Soroukou, C. F., \& Weissbrod, C. S. (2005). "Men and women's attachment and contact patterns with parents during the first year of college", Journal of Youth and Adolescence, 34, 221-228.

[25] Sundarasen, S. D. D., Rahman, M. S., Othman, N. S., \& Danaraj, J. (2016), "Impact of financial literacy, financial socialization agents, and parental norms on money management", Advanced Science Letters, 22(12), 4312-4315.

[26] Tang, N. and Peter, P. C. (2015), "Financial knowledge acquisition among the young: The role of financial education , financial experience , and parents 'financial experience', 


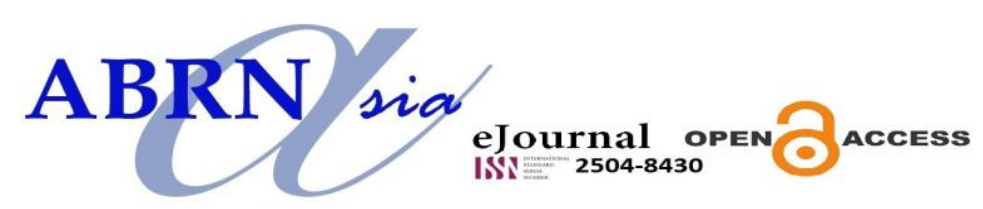

Asia Pacific Journal of Social Science Research

Volume 5 Issue 12020

"24, pp. 119-137.

[27] Tinto, V. (1988), "Stages of student departure: Reflections on the longitudinal character of student leaving." ,Journal of Higher Education, 59, 438-455

[28] Xiao, J. J., Ahn, S. Y., Serido, J., \& Shim, S. (2014), "Earlier financial literacy and later financial behaviour of college students", International Journal of Consumer Studies, 38(6), 593-601. https://doi.org/10.1111/ijcs.12122

\section{BIOGRAPHY}

\section{Gianina Nadya Putri}

Final year undergraduate student in School of Business and Management from Institut Teknologi Bandung. Has experienced in managing start up "Anakost", mobile application to fulfill student daily needs as one of the school project together with her fellow students mate. Currently work as Financial Staff for "Lokapoin", travel and tourism start up from ITB. Together with her teammates won some student group awards such as 2018 LMP Best Beauty Company and 2019 Best Investment Company for Capital Market course. Has done some teaching voluntary projects in the education field "Kelas Inspirasi" together with Satoe Indonesia in 2018.

\section{Raden Aswin Rahadi}

Worked for 15 years in real estate, property, architecture, design, investment management, financial consulting, and research industry. Holds a bachelor degree in Architecture Engineering from Institut Teknologi Bandung, hold two degrees in Management from Swiss German University, Indonesia and in Business Administration from Fachhochschule Konstanz - Hochschule für Technik, Wirtschaft und Gestaltung, Germany, holds a Doctorate in Management Science from School of Business and Management,Institut teknologi Bandung. Holds Qualified Wealth Planner (QWP ®) certification from IAFP Global, International NLP Basic Practitioner Certificate from National Federation of NeuroLinguistic Programming (NFNLP), and Registered Financial Associate (RFA®) Certificate from IARFC.

\section{Adhya Rare Tiara}

Graduated from Industrial Engineering, Institut Teknologi Bandung (ITB) in 2014. She was a fast-track student and got her master degree from Industrial Engineering and Management in the next year. After completed her master degree, she worked as a part-time lecturer in Telkom University and Institut Teknologi Nasional (Itenas). She also worked in consulting industry for 4 years and was involved in several projects with Indonesian State-Own Enterprise. In 2018 she published a research about value chain and innovation in Int. J. Technological Learning, Innovation and Development.Graduated Worked. Currently, she works as part-time lecturer in School of Business and Management ITB. 